DAFTAR ISI :

Volume XII No. 1 Desember 2009

ANALISIS BEBERAPA FAKTOR YANG MEMPENGARUHI PENERIMAAN PAJAK HIBURAN DI KOTA SURABYA Veronika Nugraheni Sri Lestari Sri Handini

16

HUBUNGAN KAUSALITAS (GRANGER) PENDAPATAN NASIONAL DENGAN JUMLAH UANG BEREDAR DI INDONESIA (1990 - 2007)

Lumadya Adi

33

ANALISIS KEPUASAN MASYARAKAT TERHADAP KUALITAS LAYANAN PUSKESMAS DI KABUPATEN BANGKALAN

Ilya Farida

Sandra Oktaviana Pinaraswati

53

ANALISIS PENGARUH RASA, KEMASAN, HARGA DAN IKLAN TERHADAP KEPUTUSAN PEMBELIAN MINUMAN FRESTEA PADA MAHASISWA FAKULTAS EKONOMI UNIVERSITAS DR. SOETOMO SURABAYA Moh. Rusman

ANALISA PENGARUH FAKTOR-FAKTOR EKONOMI TERHADAP TINGKAT PENGANGGURAN DI SURABAYA Endang Susetyowati

POLA KOMUNIKASI RUMAH TANGGA PENDUDUK MALAYSIA DAN IMPLIKASINYA TAHUN 1990-2007 (Pendekatan : Autorgegresif Distributed Lag) Wiwik Budiarti Sri Handini

97

STUDI KOMPARATIF PERTUMBUHAN EKONOMI LIMA NEGARA INDUSTRI MAJU DENGAN LIMA NEGARA ANGGOTA ASEAN $2001-2006$ Budiono

\section{JOURNAL}

MAJALAH ILMU EKONOMI \& BISNIS

FAKULTAS EKONOMI - UNIVERSITAS DR. SOETOMO

PEMIMPIN REDAKSI :

Lumadya Adi, Drs., M.Si

WAKIL PEMIMPIN REDAKSI : Ilya Farida, SE.,MM

REDAKTUR KHUSUS :

Santoso S. Hamijoyo, Prof.Dr.,M.Sc.,Ph.D

Sri Edi Swasono, Prof., Dr.

Djumilah Zein, Prof.,Dr. Iwan Triyuwono, Dr Noor Sutrisno, Dr Sukesi, Dr., MM

Wahjudi Noor Saleh, Drs., Ec.,MM

Slamet Riyadi, Drs.,Ec.,MP.,MM

Darto Irawan, SE.,MM Indrarini Utoro, Dra.Ec.,MM

Endang Susetyowati, Dra.,Ec.,MM

Djoko Sudiro, Drs., M.Si

Miftahol Horri, Drs. M.Si., Ak

\section{REDAKTUR :}

Rina Sulistyani, Dra., Ec Muhammad Gozali Tafalas, SE., M.Si

Nur Sayidah, SE.,M.Si., Ak

ALAMAT REDAKTUR :

Fakultas Ekonomi Universitas Dr. Soetomo

Jl. Semolowaru 84 Surabaya

Telp. 031-5944752 Fax. 031-5964838

http : //ekonomi.unitomo.ac.id email : ekonomi@unitomo.ac.id journalfe@unitomo.ac.id

ISSN : 0854-4883 



\title{
ANALISIS BEBERAPA FAKTOR YANG MEMPENGARUHI PENERIMAAN PAJAK HIBURAN DI KOTA SURABAYA
}

\author{
Veronika Nugraheni Sri Lestari \\ Sri Handini
}

Fakultas Ekonomi Universitas Dr. Soetomo

\begin{abstract}
This research is using secondary data that obtained from East Java Statistic Center Office and Surabaya Taxation Department, started from 1991-2005, and then the data is analyzed by using multiple linier regression analysis through $F$ test and $t$ test. The conclusion of this research simultaneously shows the real relation of Inflation Level, Number of Entertainment Place, Income per Capita and number of Tax Collection to the Acceptance of Entertainment Tax in Surabaya with testing result $F$ count $=14,185>F$ table $=3,48$ meanwhile partially, Inflation Level (XI) has no real influence to the Acceptance of Entertainment in Surabaya (Y)and it is shown from the value that obtained in which $t$ count $=-0,045<t$ table $=2,228$ partial variable, number of Entertainment Place (X2) has real influence to The Acceptance of Entertainment Tax in Surabaya $(Y)$ with result value $t$ count $=3,266>t$ table $=2,228$, Income per capita (X3) variable has real influence to the Acceptance of Entertainment in Surabaya $(Y)$ and it is shown with value oft count $=5,725>t$ table $=2,228$ and Number of Tax Collection (X4) variable has no real influence to the Acceptance of Entertainment Tax in Surabaya $(Y)$ and it is shown with the value of count = $-0,457<$ t table $=2,228$.
\end{abstract}

Key Words : Inflation Level, Number of Entertainment Place, Income per Capita and number of Tax Collection 
Riset ini menggunakan data sekunder yang diperoleh dari Kantor Pusat Statistik Jawa Timur dan Surabaya Departemen Perpajakan, dimulai dari 1991-2005, dan kemudian data dianalisa dengan menggunakan berbagai analisis linier regresi melalui $\mathrm{F}$ test dan $\mathrm{t}$ test.

Kesimpulan dari riset ini secara bersama menunjukkan hubungan Tingkatan Inflasi yang riil, Jumlah Tempat Pertunjukan, Pendapatan per kapita dan jumlah Pungutan Pajak terhadap Penerimaan dari Pajak Tontonan di Surabaya dengan menguji hasil $\mathrm{F}$ hitung $=14,185>\mathrm{F}$ table $=3,48$ sementara itu secara parsial, Tingkatan Inflasi ( X1) tidak punya pengaruh riil kepada Penerimaan terhadap Pertunjukan di Surabaya (Y) itu ditunjukkan dari nilai yang diperoleh di mana $t$ hitung $=-0,045<\mathrm{t}$ tabel $=2,228$ variabel parsial, jumlah Tempat Pertunjukan $(\mathrm{X} 2)$ mempunyai pengaruh riil kepada Penerimaan terhadap Pajak Tontonan Surabaya (Y) dengan nilai hasil $\mathrm{t}$ hitung $=3,266>\mathrm{t}$ table $=2,228$, Pendapatan per kapita (X3) variabel mempunyai pengaruh rid kepada Penerimaan terhadap Pertunjukan di Surabaya $(Y)$ itu ditunjukkan dengan nilai t hitung= 5,725> t table $=2,228$ dan Jumlah Pungutan Pajak (X4) Variabel tidak punya pengaruh rid 14epada Penerimaan terhadap Pajak Tontonan di Surabaya (Y) dan ditunjukkan dengan nilai t hitung $=-0,457<\mathrm{t}$ tabel 2,228.

Kata Kunci: Tingkatan Inflasi, Jumlah Tempat Pertunjukan, Pendapatan per kapita dan jumlah Pungutan Pajak 


\section{PENDAHULUAN}

\section{Latar Belakang}

Pajak merupakan salah satu perwujudan kewajiban kenegaraan tanp kecuali. Sesuai Undang-Undang Nomor 22 tahun 1999 tentang pokok- pokok Pemerintah Daerah, dijelaskan bahwa Anggaran Pendapatan dan Belanja Daerah (APBD) bersumber dari Pendapatan Ash Daerah (PAD), sehingga Pendapatan Ash Daerah yang antara lain diperoleh dari Pajak Daerah dan Retribusi daerah di harapkan menjadi salah satu sumber pembiayaan penyelenggaraan pemerintahan dan pembangunan daerah untuk meningkatkan dan memeratakan kesejahteraan masyarakat, serta membangun' daerahnya sendiri, dengan pemberian hak otonomi.

Surabaya sebagai daerah heterogen penduduk, budaya, bahasa dan beraneka ragam kegiatan serta ditambah dengan kesibukan-kesibukan yang mewarnai setiap saat, maka tepat sekali pemerintah melalui instansi terkait bekerja sama dengan swasta untuk menandakan jenis dan tempat hiburan bagi masyarakat yang membutuhkan, karena dari jenis dan tempat hiburan itu dapat di pungut pajak yaitu Pajak Hiburan.

Peneliti tertarik untuk melakukan penelitian ini karena Pajak hiburan sebagai salah satu pajak daerah yang mempunyai peranan cukup besar tentang pengaruh Tingkat Inflasi, Jumlah Tempat Hiburan, Pendapatan Perkapita dan Jumlah Pemungut Pajak terhadap Penerimaan Pajak Hiburan di kota Surabaya.

\section{Tujuan Penelitian}

Tujuan Penelitian ini adalah :

1. Menganalisa seberapa besar pengaruh Tingkat Inflasi, Jumlah Tempat Hiburan, Pendapatan Perkapita dan Jumlah Pemungut Pajak terhadap Penerimaan Pajak Hiburan di Kota Surabaya.

2. Menganalisa faktor yang dominan di antara Tingkat Inflasi, Jumlah Tempat Hiburan, Pendapatan Perkapita dan Jumlah Pemungut Pajak terhadap Penerimaan Pajak Hiburan di Kota Surabaya. 


\section{Perumusan Masalah}

Perumusan masalah dalam penelitian ini adalah :

1. Apakah ada pengaruh antara Tingkat Inflasi, Jumlah Tempat Hiburan, Pendapatan Perkapita dan Jumlah Pemungut Pajak terhadap Penerimaan Pajak Hiburan di Kota Surabaya.

2. Apakah faktor yang dominan di antara Tingkat Inflasi, Jumlah Tempat Hiburan, Pendapatan Perkapita dan Jumlah Pemungut Pajak terhadap Penerimaan Pajak Hiburan di Kota Surabaya.

\section{STUDI PUSTAKA}

\section{Penelitian Terdahulu}

Nyoman Widiastuty (2002). "Beberapa Faktor yang Mempengaruhi Penerimaan Pajak Kendaraan Bermotor di Kota Probolinggo”. Dari hasil analisis pengujian secara simultan bahwa variabel bebas berpengaruh secara nyata terhadap variabel terikat dengan nilai $=F_{\text {hitung }}=87,956>F_{\text {tabel }}=5,41$ menggunakan level of significant sebesar $\alpha=0,05$. sedangkan dari pengujian secara parsial, menggunakan uji t dengan $\alpha / 2=0,025$, dapat diketahui bahwa variabel bebas jumlah kendaraan (X1) berpengaruh secara nyata terhadap variabel terikat dengan $t_{\text {hitung }} 8,787>t_{\text {tabel }} 2,571$, untuk variabel bebas TPAK (X2) diperoleh $\mathrm{t}_{\text {hitung }}=2,589>\mathrm{t}_{\text {tabel }}=2,571$ yang berarti bahwa TPAK berpengaruh nyata terhadap pajak kendaraan bermotor, untuk variabel bebas inflasi (X3) diperoleh $t_{\text {hitung }}=-3,670<-\mathrm{t}_{\text {tabel }}=-2,571$ yang berarti bahwa inflasi berpengaruh nyata terhadap pajak kendaraan bermotor.

Doni Priyono (2004) "Beberapa faktor yang mempengaruhi penerimaan Pajak Kendaraan Bermotor di Kabupaten Nganjuk", dari hasil pengujian menunjukkan bahwa jumlah kendaraan bermotor (X1), Pendapatan perkapita (X2) dan inflasi (X3) secara simultan memiliki pengaruh terhadap keberhasilan penerimaan pajak kendaraan bermotor di Kabupaten Nganjuk (Y). dan faktor yang paling dominan berpengaruh terhadap keberhasilan penerimaan pajak kendaraan bermotor di Kabupaten Nganjuk adalah jumlah kendaraan bermotor. 


\section{Landasan Teori}

1. Pengertian Pajak Daerah

Dalam Undang-undang Nomor 34 Tahun 2000 tentang Pajak Daerah dan Retribusi Daerah, yang dimaksud Pajak Daerah yang selanjutnya disebut pajak, adalah iuran wajib yang dilakukan oleh orang pribadi atau badan kepada Daerah tanpa imbalan langsung yang seimbang, yang dapat dipaksakan berdasarkan peraturan perundang-undangan yang berlaku, yang digunakan untuk membiayai penyelenggaraan Pemerintahan Daerah dan Pembangunan Daerah.

Sesuai dengan pembagian administrative daerah maka pajak daerah dapat digolongkan menjadi 2 (dua) jenis, yaitu

a. Pajak Propinsi

Macam atau jenisnya adalah

1. Pajak Kendaraan Bermotor dan Kendaraan di Atas Air,

2. Bea Balik Nama Kendaraan bermotor dan Kendaraan di Atas Air;

3. Pajak bahan bakar kendaraan bermotor;

4. Pajak pengambilan dan pemanfaatan air bawah tanah dan air permukaan.

b. Pajak Kabupaten / Kota

Macam atau jenisnya adalah

1. Pajak Hotel;

2. Pajak Restoran;

3. Pajak Hiburan;

4. Pajak Reklame;

5. Pajak Penerangan Jalan;

6. Pajak Pengambilan Bahan Galian Golongan C;

7. Pajak Parkir 


\section{HIPOTESIS}

Hipotesis dalam penelitian ini adalah

a. Diduga Tingkat Inflasi, Jumlah Tempat Hiburan, Pendapatan Perkapita dan Jumlah Pemungut Pajak berpengaruh signifikan terhadap Penerimaan Pajak Hiburan di Kota Surabaya.

b. Diduga Pendapatan Perkapita mempunyai pengaruh dominan terhadap Penerimaan Pajak Hiburan di Kota Surabaya.

\section{METODOLOGI PENELITIAN}

\section{Data dan Sumber Data}

Data yang digunakan dalam penelitian ini adalah data sekunder, sumber data yang diterbitkan oleh Badan Pusat Statistik (BPS), Dinas Pariwisata (Disparta), Dinas Pajak Tingkat 11 Kota Surabaya dan data-data pendukungnya lainnya yang berasal dari studi pustaka, dari tahun 1991 - 2005. Variabel-variabel dalam penelitian ini meliputi ; Penerimaan Pajak Hiburan (Y) adalah Variabel Terikat. Variabel Bebas (X) adalah Tingkat Inflasi (X,), Jumlah Tempat Hiburan (X2), Pendapatan Perkapita (X3), dan Jumlah Petugas Pemungut Pajak (X4).

Data yang diolah penulis sajikan sebagai berikut:

\section{Tabel 4.1}

Data Input

\begin{tabular}{|c|c|c|c|c|c|}
\hline Tahun & $\mathbf{Y}$ & $\mathbf{X 1}$ & $\mathbf{X 2}$ & $\mathbf{X 3}$ & $\mathbf{X 4}$ \\
\hline 1991 & 4010784000 & 9,97 & 553 & 941.25 & 35 \\
\hline 1992 & 4854054000 & 5,28 & 540 & 1060,41 & 33 \\
\hline 1993 & 5725102000 & 10,19 & 549 & 3662,5 & 32 \\
\hline 1994 & 5444248000 & 8,25 & 587 & 3951,86 & 30 \\
\hline 1995 & 6052546000 & 7,2 & 598 & 4357,38 & 27 \\
\hline 1996 & 5303285000 & 6,68 & 615 & 4660,97 & 25 \\
\hline 1997 & 5073063000 & 9,11 & 619 & 4840,58 & 24 \\
\hline 1998 & 5212444000 & 95,21 & 636 & 3909,55 & 23 \\
\hline 1999 & 5878160000 & 1,39 & 653 & 3896,43 & 25 \\
\hline 2000 & 5043583000 & 10,46 & 662 & 13293,65 & 28 \\
\hline
\end{tabular}




\begin{tabular}{|c|c|c|c|c|c|}
\hline Tahun & $\mathbf{Y}$ & $\mathbf{X 1}$ & $\mathbf{X 2}$ & $\mathbf{X 3}$ & $\mathbf{X 4}$ \\
\hline 2001 & 6839962000 & 14,13 & 701 & 13783,32 & 30 \\
\hline 2002 & 7711516000 & 9,15 & 697 & 14231,60 & 31 \\
\hline 2003 & 8784662000 & 4,79 & 487 & 14737,05 & 32 \\
\hline 2004 & 10540421843 & 5,92 & 531 & 15441,41 & 33 \\
\hline 2005 & 11515307018 & 2,28 & 326 & 16293,03 & 34 \\
\hline
\end{tabular}

\section{Alat Analisis}

Regresi linier berganda dengan persamaan Sudrajat (1998:122)

$$
\mathrm{Y}=\beta \mathrm{o}+\beta_{1} \mathrm{X}_{1}+\beta_{2} \mathrm{X}_{2}+\beta_{3} \mathrm{X}_{3}+\beta_{4} \mathrm{X}_{4}+\mathrm{e}
$$

Dimana :

$$
\begin{array}{ll}
\mathrm{Y} & =\text { Besarnya penerimaan pajak hiburan } \\
\mathrm{X} 1 & \text { Tingkat inflasi } \\
\mathrm{X} 2 & \text { Jumlah tempat hiburan } \\
\mathrm{X} 3 & \text { Pendapatan perkapita } \\
\mathrm{X} 4 & \text { Jumlah pemungut pajak } \\
130 & \text { Konstanta } \\
\beta_{1}, \beta_{2}, \beta_{3}, \beta_{4}= & \text { Koefisien regresi } \\
\mathrm{e} & \text { Variabel pengganggu yang mewakili faktor-faktor yang } \\
& \text { berpengaruh terhadap penerimaan Pajak Hiburan, namun tidak } \\
& \text { termasuk ke dalam model }
\end{array}
$$

\begin{tabular}{|c|c|}
\hline Variabel & Koefisien Regresi \\
\hline Tingkat Inflasi (X1) & $-586839,825$ \\
\hline Jumlah Tempat Hiburan (X2) & 11183310,388 \\
\hline Pendapatan Perkapita (X3) & 277329,005 \\
\hline Jumlah Pemungut Pajak (X4) & $-42315431,442$ \\
\hline \multicolumn{2}{|c|}{$\begin{array}{l}\text { Variabel terikat: Penerimaan Pajak Hiburan di Kota Surabaya Konstanta: } 121 \\
\text { 12637707.694 }\end{array}$} \\
\hline
\end{tabular}

\section{HASIL DAN PEMBAHASAN PENELITIAN}

Hasil penelitian penulis sajikan ke dalam bentuk tabel seperti berikut ini:

Tabel 5.1

Hasil Perhitungan Regresi Linier Berganda dengan Menggunakan Program SPSS 13

Sumber : Data diolah 
Berdasarkan dari hasil perhitungan pengolahan data dengan bantuan komputer program SPSS (Statistical Program for Social Science) maka diperoleh persamaan regresi linier berganda sebagai berikut :

$$
\begin{aligned}
\mathrm{Y}= & 12112637707,694--586839,825 \mathrm{X}_{1}+11183310,388 \mathrm{X}_{2}+ \\
& 277329,005 \mathrm{X}_{3}--42315431,442 \mathrm{X}_{4}
\end{aligned}
$$

Dimana :

$\beta$ o Konstanta $=12112637707,694$ Jika diasumsikan $\mathrm{X}_{1}, \mathrm{X}_{2}, \mathrm{X}_{3}$, dan $\mathrm{X}_{4}$ konstan maka nilai Y akan mengalami kenaikan sebesar Rp. 12112637707,694 .

$\beta_{1}$

$=-586839,825$ artinya setiap kenaikan $\mathrm{X}$, (Tingkat Inflasi) sebesar 1 persen akan menyebabkan penurunan nilai $\mathrm{Y}$ (Penerimaan Pajak Hiburan di Kota Surabaya) sebesar Rp. 586839,825 dengan asumsi X2, X3 dan X4 konstan.

$\beta_{2} \quad=11183310,388$ artinya setiap kenaikan X2 (Jumlah Tempat Hiburan) sebesar I unit akan menyebabkan kenaikan Y (Penerimaan Pajak Hiburan di Kota Surabaya) sebesar Rp. 11183310,388 dengan asumsi X1, X3 dan X4 konstan.

$\beta_{3} \quad=277329,005$ artinya setiap kenaikan X3 (Pendapatan Perkapita) sebesar Rp. 1 ribu menyebabkan kenaikan Y (Penerimaan Pajak Hiburan di Kota Surabaya) sebesar Rp. 277329,005 dengan asumsi X1, X2 dan X4 konstan.

$\beta_{4} \quad=-42315431,442$ artinya setiap kenaikan X4 (Jumlah Pemungut Pajak) sebesar 1 orang menyebabkan penurunan $\mathrm{Y}$ (Penerimaan Pajak Hiburan di Kota Surabaya) sebesar Rp. 42315431,442 dengan asumsi X1, X2 dan X3 konstan.

Tabel 5.2

Hasil Perhitungan Uji F

\begin{tabular}{|l|r|c|r|c|c|}
\hline & \multicolumn{1}{|c|}{ Jumlah kuadrat } & DF & \multicolumn{1}{c|}{ Kuadrat Tengah } & Fhitung & Ftabel \\
\hline Regresi & 56722761518691700000 & 4 & 14180690379672940000 & 14,185 & 3,48 \\
Residual & 9997167597079100000 & 10 & 999716759707910000 & & \\
Total & 66719929115770800000 & 14 & & & \\
\hline
\end{tabular}

Sumber : Data diolah 
Untuk pengujian hipotesis penelitian pengaruh secara simultan antara variabel bebas terhadap variabel terikat maka ditetapkan langkah-langkah sebagai berikut :

1. Ho : $\beta_{1},=\beta_{2}=\beta_{3}=\beta_{4}=0$

(Artinya, Tingkat Inflasi, Jumlah Tempat Hiburan, Pendapatan Perkapita dan Jumlah Pemungut Pajak secara bersama-sama tidak berpengaruh signifikan terhadap Penerimaan Pajak Hiburan di Kota Surabaya)

$\mathrm{HI}: \beta_{1}=\beta_{2}=\beta_{3}=\beta_{4} \neq 0$

(Artinya, Tingkat Inflasi, Jumlah Tempat Hiburan, Pendapatan Perkapita dan Jumlah Pemungut Pajak secara bersama-sama berpengaruh signifikan terhadap Penerimaan Pajak Hiburan di Kota Surabaya)

2. Tingkat signifikansi $(\alpha)=5 \%$

3. $\mathrm{F}_{\text {tabel }}(\mathrm{df}$ pembilang / $\mathrm{k} ; \mathrm{df}$ penyebut / $\mathrm{n}-\mathrm{k}-1)$

$\mathrm{F}_{\text {tabel }}(4 ; 10)=3,48$.

4. Kriteria penerimaan dan penolakan hipotesis

a. Apabila $\mathrm{F}_{\text {hitung }}<3,48$, maka Ho diterima atau $\mathrm{H}_{1}$ ditolak

b. Apabila $\mathrm{F}_{\text {hitung }}<3,48$, maka Ho ditolak atau $\mathrm{H}_{1}$ diterima

5. $\quad$ F hitung $=\frac{\text { Kuadrat Tengah Regresi }}{\text { Kuadrat Tengah Residual }}$

$$
=\frac{14180690379672940000}{999716759707910000}=14,185
$$

Hasil perhitungan uji t penulis sajikan dalam bentuk tabel sebagai berikut:

Tabel 5.3

Hasil Perhitungan Uji t

\begin{tabular}{|c|c|c|c|c|c|}
\hline Variabel & $\begin{array}{c}\text { Koefisien } \\
\text { Regresi }\end{array}$ & Std Error & $\mathbf{t}_{\text {hitung }}$ & $\mathbf{t}_{\text {tabel }}$ & $\mathbf{r}^{2}$ parsial \\
\hline $\begin{array}{c}\text { Tingkat } \\
\text { Inflasi (XI) }\end{array}$ & $-586839,825$ & 13137585,986 & $-0,045$ & 2,228 & 0,00020 \\
\hline $\begin{array}{c}\text { Jumlah } \\
\text { Tempat } \\
\text { Hiburan } \\
(\mathrm{X} 2)\end{array}$ & 11183310,388 & 3423929,870 & 3,266 & 2,228 & 0,515 \\
\hline
\end{tabular}




\begin{tabular}{|c|c|c|c|c|c|}
\hline Variabel & $\begin{array}{c}\text { Koefisien } \\
\text { Regresi }\end{array}$ & Std Error & $\mathbf{t}_{\text {hitung }}$ & $\mathbf{t}_{\text {tabel }}$ & $\mathbf{r}^{2}$ parsial \\
\hline $\begin{array}{c}\text { Pendapatan } \\
\text { Perkapita } \\
\text { (X3) }\end{array}$ & 277329,005 & 48441,617 & 5,725 & 2,228 & 0,766 \\
\hline $\begin{array}{c}\text { Jumlah } \\
\text { Pemungut } \\
\text { Pajak (X4) }\end{array}$ & $-42315431,442$ & 92633891,326 & $-0,457$ & 2,228 & 0,020 \\
\hline \\
Variabel terikat: Penerimaan Pajak Hiburan di Kota Surabaya \\
Sumber : Data diolah
\end{tabular}

a. Uji parsial antara Tingkat Inflasi $\left(\mathrm{X}_{1}\right)$ terhadap Penerimaan Pajak Hiburan di Kota Surabaya (Y) digunakan uji t dan langkah-langkah sebagai berikut

1. Ho : $\beta_{1}=0$ (tidak ada pengaruh signifikan antara variabel $\mathrm{X}_{\mathrm{i}}$ terhadap variabel Y)

Ho : $\beta_{1} \neq 0$ (ada pengaruh signifikan antara variabel $\mathrm{X}_{\mathrm{i}}$ terhadap variabel Y)

2. $\frac{\alpha}{2}=0,025$ dengan $\mathrm{df}=10$

$$
\mathrm{T}_{\text {tabel }}\left(\frac{\alpha}{2}=0,025\right)=2,228
$$

3. $\mathrm{t}_{\text {hitung }}=\frac{\beta_{1}}{\operatorname{Se}\left(\beta_{1}\right)}=-0,045$

\section{SIMPULAN DAN SARAN}

\section{Simpulan}

1. Setelah dilakukan uji statistik untuk mengetahui Tingkat Inflasi, Jumlah Tempat Hiburan, Pendapatan Perkapita dan Jumlah Pemungut Pajak terhadap Penerimaan Pajak Hiburan di Kota Surabaya, yaitu secara simultan atau keseluruhan diperoleh hasil dimana $\mathrm{F}_{\text {hitung }}=14,185>\mathrm{F}_{\text {tabel }}=3,48$ pada tingkat $\alpha=5 \%$ maka Ho ditolak dan Hi (hipotesis alternative) diterima. Hal ini menunjukkan bahwa tingkat Inflasi, Jumlah Tempat Hiburan, Pendapatan Perkapita dan Jumlah Pemungut Pajak secara bersama-sama berpengaruh terhadap Penerimaan Pajak Hiburan di Kota Surabaya. 
2. a. Uji parsial. antara Tingkat Inflasi terhadap Penerimaan Pajak Hiburan di Kota Surabaya diketahui hasil perhitungan secara parsial diperoleh $t_{\text {hitung }}=$ $-0,045<$ tabel $=2,228$. Sehingga secara parsial Tingkat Inflasi $\left(\mathrm{X}_{1}\right)$ tidak berpengaruh nyata terhadap Penerimaan Pajak Hiburan di Kota Surabaya (Y). Hal tersebut dikarenakan keadaan perekonomian yang masih belum stabil dan terjadi kenaikan harga-harga kebutuhan pokok dan lain sebagainya sehingga akan menurunkan penerimaan pajak hiburan di Kota Surabaya. Sedangkan bisnis Tempat Hiburan merupakan investasi jangka panjang yang dianggap sebagian pengusaha menguntungkan dengan anggapan membaiknya perekonomian di masa datang.

b. Uji parsial Jumlah Tempat Hiburan terhadap Penerimaan Pajak Hiburan di Kota Surabaya diketahui hasil perhitungan diperoleh $\mathrm{t}_{\text {hitung }}=3,266>\mathrm{t}_{\text {tabel }}=$ 2,228. Sehingga secara parsial Jumlah Tempat Hiburan (X2) berpengaruh nyata terhadap Penerimaan Pajak Hiburan di Kota Surabaya (Y). Hal tersebut dikarenakan semakin banyak obyek pajak dalam hal ini tempat hiburan yang dikunjungi masyarakat maka akan mempengaruhi subyek pajak untuk mengunjungi tempat-tempat hiburan yang semakin meningkatkan penerimaan pajak hiburan di Kota Surabaya.

c. Uji parsial antara Pendapatan Perkapita terhadap Penerimaan Pajak Hiburan di Kota Surabaya diperoleh $t_{\text {hitung }}=5,725>t_{\text {tabel }}=2,228$. Sehingga secara parsial variabel Pendapatan Perkapita (X3) berpengaruh nyata terhadap Penerimaan Pajak Hiburan di Kota Surabaya (Y). Hal tersebut dikarenakan apabila jumlah pendapatan perkapita meningkat maka kemampuan masyarakat untuk mengunjungi tempat hiburan akan bertambah dan penerimaan pajak hiburan di Kota Surabaya akan meningkat.

d. Uji parsial antara Jumlah Pemungut Pajak terhadap Penerimaan Pajak Hiburan di Kota Surabaya diperoleh $\mathrm{t}_{\text {hitung }}=-0,457<\mathrm{t}_{\text {tabel }}=2,228$. Sehingga secara parsial Jumlah Pemungut Pajak (X4) tidak berpengaruh nyata terhadap Penerimaan Pajak Hiburan di Kota Surabaya (Y). hal tersebut disebabkan semakin berkembangnya teknologi pada saat ini mengakibatkan para wajib pajak tidak perlu membayar langsung secara 
tunai kepada pemungut pajak tetapi bisa dilakukan lewat bank-bank yang telah ditunjuk oleh dinas pajak.

\section{Saran-saran}

1. Pemerintah Kota Surabaya hendaknya meninjau kembali kebijakan tentang pajak hiburan di Kota Surabaya agar investor atau pengusaha dapat membangun tempat hiburan yang pada akhirnya akan meningkatkan pendapatan daerah dari sektor pajak.

2. Pemerintah Kota Surabaya hendaknya lebih memperhatikan tentang tersedianya tempat hiburan yang memadai dan nyaman agar masyarakat Kota Surabaya mempunyai tujuan untuk menghabiskan waktu bersama keluarga, disisi lain pajak yang didapat dari tempat hiburan tersebut akan mengalami peningkatan. 


\section{DAFTAR PUSTAKA}

Agustyarini, Penny, 2003, Analisis Beberapa Faktor Yang Mempengaruhi Penerimaan Pajak Hiburan Sebagai Salah Satu Pendapatan Daerah di Kotamadya Surabaya, FE-IESP, UPN "Veteran” Jawa Timur, Surabaya.

Algifari, 2000, Analisis Regresi: Teori, Kasus dan Solusi, Edisi 2, Cetakan Pertama, Penerbit BPFE, Yogyakarta.

Anonim, 2004, Dinas Pariwisata Daerah Surabaya.

Anonim, 1999, Surabaya Dalam Angka, Badan Pusat Statistik Surabaya. Anonim, 2005, Surabaya Dalam Angka, Badan Pusat Statistik Surabaya.

Boediono, 2001, Pengantar Ilmu Ekonomi No. 2 Ekonomi Makro, Penerbit BPFE, Yogyakarta.

Brotodiharjo, Santoso, 1995, Pengantar Ilmu Hukum Pajak, Edisi Ketiga, Penerbit PT Eresco, Bandung.

Insukindro, 1996, Teori Ekonomi Makro I, Penerbit Karunia, Jakarta. Manullang, 1993, Ekonomi Moneter, Penerbit Galia Indonesia, Medan.

Munawir, H.S, 1992, Perpajakan, Edisi Keempat, Cetakan Pertama, Penerbit Liberty Yogyakarta, Yogyakarta.

Nopirin, 2000, Ekonomi Moneter, Buku dua, Edisi Pertama, Cetakan Kesepuluh, Penerbit BPFE. Yogyakarta.

Pandiangan, Liberty, 2002, Pemahaman Praktis Undang-Undang Perpajakan Indonesia, Penerbit Erlangga, Jakarta.

Patirant, Siti Nadhya, 2003, Faktor faktor Yang Mempengaruhi Penerimaan Pajak Pariwisata di Kabupaten FakFak, Fe-IESP, UPN "Veteran" Jawa Timur, Surabaya.

Priyono, Dani, 2004, Beberapa Faktor Yang Mempengaruhi Penerimaan Pajak Kendaraan Bermotor di Kabupaten Nganjuk. FE-IESP Unitomo Jawa Timur, Surabaya.

Samuleson, Paul A, 1993, Mikro Ekonomi, Penerbit Erlangga, Jakarta.

Saputra, Gunadi Ragil, 2006, Analisis Beberapa Faktor Yang Mempengaruhi Penerimaan Pajak Hiburan Sebagai Salah Satu Pendapatan Daerah di Kota Surabaya, FE-IESP, UPN "Veteran” Jawa Timur, Surabaya. 
Siahaan, Marihot. P, 2005, Pajak Daerah dan Retribusi Daerah, penerbit PT Raja Grafindo Persada, Jakarta.

Soemarso, SR, 1998, "Dampak Reformasi Perpajakan 1984 terhadao Efisiensi Sistem Perpajakan Indonesia", Jurnal Ekonomi dan Keuangan Indonesia, Vol. XLVI, No. 3, Hal. 337-338.

Sukimo, Sadono, 1993, Ekonomi Pembangunan: Proses, Masalah, dan Dasar Kebyaksanaan, Penerbit Fakultas Ekonomi UI dengan Bima Grafika, Jakarta.

Sulaiman, Wahid, 2004, Analisis Regresi Menggunakan SPSS, Penerbit Andi, Yogyakarta.

Soemitro, Rokhmat, 1992, Asas dan Dasar Perpajakan, Cetakan Kelima, Penerbit PT Eresco, Bandung.

Sulistya, Yeni 2005, Analisis Beberapa Faktor Yang Mempengaruhi Pendapatnasli Daerah di Kabupaten Lamongan. FE IESP UNAIR Jaw Timur, Surabaya.

Supranto, 1990, Ekonometrik, Buku Dua, Fakultas Ekonomi UI, Jakarta. Waluyo dan B. Ilyas, Wirawan, 2002, Perpajakan Indonesia, Buku Satu,

Widiastuty Nyoman, 2002, Beberapa Faktor yang Mempengaruhi Penerimaan Pajak Kendaraan Bermotor di Kota Probolinggo, FE-IESP, UPN "Veteran" Jawa Timur, Surabaya. 